\title{
4: $120600921-120596009$
}

National Cancer Institute

\section{Source}

National Cancer Institute. 4:120600921-120596009. NCI Thesaurus. Code C42240.

Physical location of FABP2_Gene 